\title{
PENGARUH PROFITABILITAS DAN INVESTMENT OPPORTUNITY SET TERHADAP KEBIJAKAN DIVIDEN DENGAN LIKUIDITAS SEBAGAI PEMODERASI
}

\author{
Ni Luh Gede Intan Sri Devi ${ }^{1}$ \\ Ni Ketut Muliati \\ 1),2) Universitas Hindu Indonesia,e-mail: Ketutmuli@yahoo.com
}

\begin{abstract}
The company's dividend policy has an important influence on many parties involved in the community. For shareholders or investors, cash dividends are the rate of return on their investment with share ownership issued by the company, but management, cash dividends are cash outflows that reduce the company's cash.

The purpose of this study was to determine the effect of profitability, investment opportunity set on cash dividend policy and to determine the effect of liquidity as a moderating variable between profitability and investment opportunity set against cash dividend policy.This research was conducted at a banking company registered on the Stock Exchange with a 5-year observation period, namely from 2011-2015. Data analysis techniques use moderated regression analysis (MRA).

The results showed that Profitability and Investment opportunity set had an effect on the cash dividend policy. Liquidity can moderate the relationship between Profitability and Investment opportunity set against world dividend policy.
\end{abstract}

Keywords : Profitability, investment opportunity set, cash dividend policy, liquidity

\section{PENDAHULUAN}

Sebuah perusahaan publik dalam melaksanakan manajemen keuangan dihadapakan pada tiga keputusan manajemen yang dapat dipilih, yaitu keputusan investasi (penggunaan dana), keputusan pendanaan (memperoleh dana) dan keputusan dividen (pembagian dividen). Tujuan sebuah perusahaan jika dilihat menurut bidang keuangan adalah untuk memakmurkan dan mensejahterakan para pemegang saham. Dalam kegiatan kerjanya, perusahaan diharapkan dapat memberikan profit untuk menambah aset perusahaan.

Likuiditas merupakan salah satu dari beberapa pertimbangan utama dalam melakukan keputusan dividen. Perusahaan yang memiliki likuiditas lebih baik akan mampu membayar dividen yang lebih banyak, dibandingkan dengan perusahaan yang 96 |widya_akuntansi 
mempunyai likuiditas kurang atau tidak baik. Likuiditas perusahaan sangat berpengaruh terhadap perusahaan dalam memperoleh laba dan dibayarkan dalam bentuk dividen kepada pemegang saham. Laba tersebut akan digunakan perusahaan untuk mendanai investasi atau dibayarkan dalam bentuk dividen. Jadi, faktor likuiditas dapat mempengaruhi hubungan antara tingkat profitabilitas dengan kebijakan dividen tunai perusahaan dan investment opportunity set terhadap kebijakan dividen tunai perusahaan. Penelitian terdahulu antara lain dilakukan oleh Suharli (2007) menghasilkan kesimpulan bahwa likuiditas dapat digunakan sebagai variabel penguat (variabel moderasi) karena memberikan hasil yang signifikan dalam mempengaruhi profitabilitas dan kesempatan investasi, tetapi dari kedua variabel independen hanya profitabilitas yang dapat mempengaruhi kebijakan jumlah pembagian dividen perusahaan. Penelitian ini menyimpulkan bahwa kebijakan jumlah pembagian dividen perusahaan dipengaruhi oleh profitabilitas dan diperkuat oleh likuiditas perusahaan.

Perbedaan penelitian ini dengan penelitian sebelumnya terletak pada tempat penelitian dan periode penelitian. Penelitian terdahulu menggunakan tempat penelitian pada perusahaan manufaktur yang listing di BEI periode 2002-2003 dengan variable profitabiitas, investment opportunity set, dividen, dan likuiditas sebagai variable pemoderasi. Sedangkan penelitian ini menggunakan tempat penelitian pada perusahaan perbankan yang terdaftar di BEI periode 2010-2015 dengan variabel profitabilitas, investment opportunity set, kebijakan dividend dan likuiditas sebagai variable pemoderasi. Penelitian ini penting karena dapat dijadikan dasar pengambilan keputusan bagi investor untuk berinvestasi pada perusahaan yang membagikan dividen, khususnya perusahaan perbankan yang membagikan dividen. Penelitian dilakukan di Bursa Efek Indonesia pada 
perusahaan perbankan dikarenakan di penelitian yang terkait sebelumnya belum ada yang menggunakan obyek penelitian perusahaan perbankan.

Rumusan masalah dalam penelitian ini yaitu : (1) Bagaimanakah pengaruh profitabilitas terhadap kebijakan dividen tunai; (2) Bagaimanakah pengaruh investment opportunity set terhadap kebijakan dividen tunai (3) Apakah likuiditas memoderasi pengaruh profitabilitas terhadap kebijakan dividen tunai; (4) Apakah likuiditas memoderasi pengaruh investment opportunity set terhadap kebijakan dividen tunai.

Tujuan dalam penelitian ini adalah : (1) Untuk mengetahui pengaruh profitabilitas terhadap kebijakan dividen tunai; (2) Untuk mengetahui pengaruh investment opportunity set terhadap kebijakan dividen tunai; (3) Untuk mengetahui apakah likuiditas yang dimiliki perusahaan dapat memoderasi pengaruh profitabilitas terhadap kebijakan dividen tunai; (4) Untuk mengetahui apakah likuiditas yang dimiliki perusahaan dapat memoderasi pengaruh investment opportunity set terhadap kebijakan dividen tunai.

Hasil penelitian ini diharapkan dapat dijadikan sebagai dasar dalam pengambilan keputusan untuk melakukan investasi pada perusahaan perbankan yang terdaftar di BEI dan Penelitian ini dapat dijadikan acuan ataupun pertimbangan dalam pengambilan keputusan perusahaan berkaitan dengan kebijakan dividen yang dipengaruhi oleh profitabilitas, dan investment opportunity set serta menambahkan likuiditas sebagai variabel moderasi antara profitabilitas dan investment opportunity set terhadap kebijakan dividen tunai perusahaan.

Profitabilitas adalah kemampuan perusahaan untuk menghasilkan keuntungan dari modal yang diinvestasikan (Hanavi:2004). Profitabilitas dalam penelitian ini diproksikan 
dengan return on asset (ROA). ROA merupakan ukuran kemampuan perusahaan menghasilkan laba bersih berdasarkan tingkat asset tertentu (Hanafi, 2004: 42). Semakin tinggi profitabilitas sebuah perusahaan, maka semakin tinggi pula arus kas dalam perusahaan tersebut, dan diharapkan perusahaan akan membayar dividen yang lebih tinggi. Penelitian yang dilakukan oleh Dewi (2016) dengan judul pengaruh investment opportunity set, free cash flow, struktur modal, profitabilitas dan likuiditas terhadap kebijakan dividen pada perusahaan manufaktur yang terdaftar di BEI tahun 2012-2014, menunjukan bahwa profitabilitas berpengaruh terhadap kebijakan dividen dan sangat signifikan. Penelitian yang dilakukan oleh Suharli (2007) tentang pengaruh profitability dan investment opportunity set terhadap kebijakan dividen tunai perusahaan dengan likuiditas sebagai variabel pemoderasi pada perusahaan manufaktur yang terdaftar di BEI periode 2002-2003 menunjukan profitabilitas berpengaruh terhadap kebijakan dividen tunai perusahaan. Dengan demikian ROA berpengaruh terhadap kebijakan dividen tunai.

\section{H1 : Profitabilitas berpengaruh positif terhadap kebijakan dividen tunai perusahaan.}

Investment opportunity set adalah keputusan investasi yang dilakukan dalam bentuk kombinasi antara antiva tetap dengan opsi investasi di masa yan akan dating dimana investasi tersebut mempengaruhi nilai perusahaan (Inneke dan Supatmi,2008). Untuk meningkatkan pertumbuhan penjualan, perusahaan memerlukan dana yang besar yang dibiayai sumber internal perusahaan. Penggunaan sumber dana internal untuk keperluan investasi, dan pembayaran dividen tunai. Kesempatan investasi diproksikan price earnings ratio (PER), Market to Book Value of Equity (MVE/BVE), dan Market Value to 99 | widya_akuntansi 
Book Value of Assets (MVA/BVA), perusahaan dengan tingkat pertumbuhan yang tinggi berarti memiliki banyak kesempatan investasi. Persamaan antara kesempatan investasi dan kebijakan dividen, yakni keduanya sama-sama bersumber dari laba perusahaan. Laba perusahaan yang akan digunakan untuk membayar dividen kepada pemegang saham dan sisanya ditahan sebagai laba ditahan yang akan digunakan untuk investasi perusahaan yang berguna untuk pertumbuhan di masa yang akan datang. Penelitian Sari (2010) dengan judul analisis pengaruh kepemilikan manajerial, kebijakan hutang, profitabilitas, ukuran perusahaan, dan kesempatan investasi terhadap kebijakan dividen tunai menyimpulkan bahwa kepemilikan perusahaan, profitabilitas, ukuran perusahaan, dan set kesempatan investasi secara parsial tidak berpengaruh terhadap kebijakan dividen tunai perusahaan. Penelitian Marpaung dan Hadianto (2009) dengan judul pengaruh profitabilitas dan kesempatan investasi terhadap kebijakan dividen pada emiten pembentuk indeks LQ45 di Bursa Efek Indonesia menyatakan bahwa kesempatan investasi tidak berpengaruh terhadap kebijakan dividen. Dengan demikian kesempatan investasi tidak berpengaruh terhadap kebijakan dividen tunai.

\section{H2 : Investment opportunity set negatif berpengaruh terhadap kebijakan dividen tunai perusahaan.}

Likuiditas adalah kemampuan perusahaan dalam memenuhi kewajiban jangka pendeknya dan memenuhi operasional perusahaan Suharli (2007). Pihak manajemen akan menggunakan potensi likuiditas untuk mendanai operasi perusahaan atau melunasi kewajiban jangka pendek. Pada perusahaan yang membukukan keuntungan yang lebih tinggi dan ditambah likuiditas yang lebih baik, maka semakin besar jumlah dividen yang akan dibagikan. Penelitian Suharli (2007) dengan judul pengaruh profitability dan 100 | widya_akuntansi 
investment opportunity set terhadap kebijakan dividen tunai dengan likuiditas sebagai variabel penguat menyatakan bahwa liuiditas dapat digunakan sebagai variabel pemoderasi karena memberikan hasil yang signifikan pada a -0.10 dalam mempengaruhi profitabilitas dan investment opportunity set terhadap kebijakan dividen tunai. Dengan demikian likuiditas dapat memperkuat pengaruh profitabilitas terhadap kebijakan dividen.

\section{H3 : Likuiditas mampu memoderasi pengaruh profitabilitas terhadap kebijakan dividen tunai perusahaan.}

Perusahan yang memiliki kondisi perusahaan yang sangat baik maka pihak manajemen cenderung akan lebih memilih investasi baru daripada membayar dividen tunai yang tinggi. Sebaliknya, perusahaan yang mengalami pertumbuhan yang lambat cenderung membagikan dividen tunai lebih tinggi untuk mengatasi masalah overinvestment (Inneke dan Supatmi, 2008). Penelitian Suharli (2007) dengan judul pengaruh profitability dan investment opportunity set terhadap kebijakan dividen tunai dengan likuiditas sebagai variabel penguat menyatakan bahwa likuiditas dapat digunakan sebagai variabel pemoderasi karena memberikan hasil yang signifikan dalam mempengaruhi investment opportunity set terhadap kebijakan dividen tunai. Jadi, likuiditas akan memperkuat pengaruh set kesempatan investasi terhadap kebijakan dividen tunai.

H4 : Likuiditas mampu memoderasi pengaruh investment opportunity set terhadap kebijakan dividen tunai perusahaan. 


\section{METODE PENELITIAN}

Penelitian ini merupakan penelitian deskriptif, di mana penelitian deskriptif termasuk dalam salah satu jenis penelitian kuantitatif. Penelitian ini mengidentifikasikan peristiwa sebagai variabel yang dipengaruhi (variabel dependen) yaitu kebijakan dividen tunai, serta melakukan penyelidikan terhadap variabel-variabel yang mempengaruhi (variabel independen) yaitu profitabilitas dan investment opportunity set. Serta menambahkan variabel pemoderasi yaitu likuiditas.

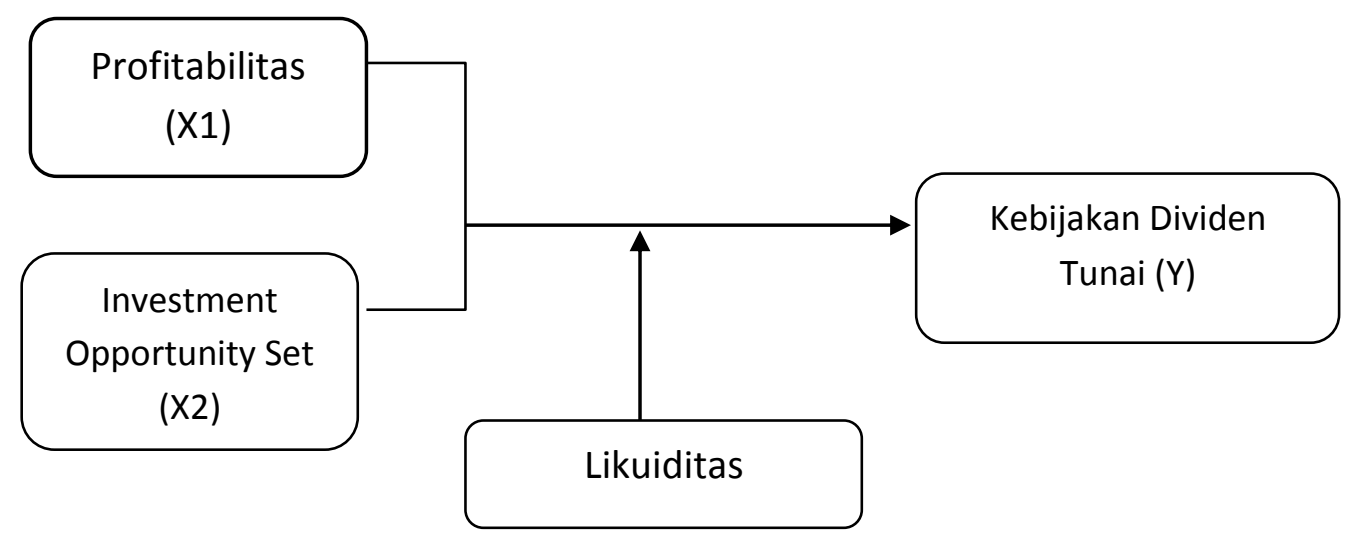

\section{Gambar 1. Desain Penelitian}

Sumber : Data Diolah

Populasi dalam penelitian ini diambil dari seluruh perusahaan perbankan yang terdaftar di Bursa Efek Indonesia (BEI) selama periode 2011-2015 yaitu sebanyak 41 perusahaan. Penentuan sampel yang digunakan dalam penelitian ini adalah teknik purposive sampling yaitu (1) Perusahaan perbankan yang sudah dan masih terdaftar di Bursa Efek Indonesia selama periode pengamatan 2011-2015; (2) Perusahaan perbankan yang mengeluarkan laporan keuangan yang sudah di audit dan menghasilkan laba bersih setiap tahun selama periode 2011-2015; (3) Perusahaan perbankan yang membagikan dividen tunai setiap tahun selama periode 2011-2015. 
Tabel 1. Sampel penelitian

\begin{tabular}{|l|l|c|}
\hline No & \multicolumn{1}{|c|}{ Keterangan } & Jumlah \\
\hline 1 & $\begin{array}{l}\text { Perusahaan perbankan yang sudah dan masih terdaftar di Bursa Efek } \\
\text { Indonesia selama periode pengamatan 2011-2015 }\end{array}$ & 41 \\
\hline 2 & $\begin{array}{l}\text { Perusahaan perbankan yang tidak mengeluarkan laporan keuangan } \\
\text { yang sudah di audit dan menghasilkan laba bersih setiap tahun selama } \\
\text { periode 2011-2015 }\end{array}$ & $\begin{array}{l}\text { Perusahaan perbankan yang tidak membagikan dividen tunai setiap } \\
\text { tahun selama periode 2011-2015 }\end{array}$ \\
\hline 3 & Perusahaan perbankan yang terpilih sebagai sampel penelitian & 9 \\
\hline \multicolumn{2}{|l|}{ Total sampel penelitian selama tahun 2011-2015 } & 45 \\
\hline
\end{tabular}

Sumber: Data diolah

Data dikumpulkan dengan menggunakan metode studi pustaka dan dokumentasi. Studi pustaka dilakukan dengan mengolah literatur, artikel, jurnal maupun media tertulis lain yang berkaitan dengan topik pembahasan dari penelitian ini. Sedangkan dokumentasi dilakukan dengan mengumpulkan sumber-sumber data dokumenter seperti laporan keuangan tahunan perusahaan yang sudah di audit periode 2011-2015 yang menjadi sampel penelitian dengan cara mengunjungi www.idx.co.id dan ICMD.

Untuk menguji pengaruh antara ROA dan PER, digunakan model regresi sederhana. Sedangkan untuk menguji pengaruh interaksi dari variabel moderasi, digunakan Moderated Regression Analysis (MRA). Persamaan statistika yang digunakan untuk membantu menentukan variabel moderator yang mendukung pengaruh antara ROA dan PER terhadap DPR (Jogiyanto, 2010) adalah sebagai berikut:

$\mathrm{DPR}_{\mathrm{t}}=\alpha+\beta \mathrm{ROA}_{\mathrm{t}}+\beta_{2} \mathrm{PER}_{\mathrm{t}}+\beta_{3} \mathrm{LDR}_{\mathrm{t}}+\beta_{4}\left(\mathrm{ROA}^{*} \mathrm{LDR}\right) \mathrm{t}+\beta_{4}(\mathrm{PER} * \mathrm{LDR}) \mathrm{t}+\mathrm{e}$

Keterangan:

$\mathrm{DPR}_{\mathrm{t}}=$ Dividend Payout Ratio (DPR), yaitu proksi dari kebijakan dividen tunai pada periode $\mathrm{t}$ 
$\alpha$

$\beta 1, \beta 2, \beta 3, \beta_{4}$

ROAt

PERt

$\mathrm{LDR}_{\mathrm{t}}$

$\mathrm{e}$
$=$ Konstanta

$=$ Koefisien regresi dari tiap-tiap variabel-variabel independen

$=$ Return on Assets (ROA), yaitu proksi dari profitabilitas pada periode $\mathrm{t}$

= Price Earnng Ratio (PER),yaitu proksi dari investment opportunity set pada periode $\mathrm{t}$

= Loan to Deposit Ratio (LDR), yaitu proksi dari likuiditas pada periode $\mathrm{t}$

$=$ galat $($ error term $)$

\section{HASIL DAN PEMBAHASAN}

Statistik deskriptif dalam penelitian ini disajikan untuk memberikan informasi mengenai karakteristik variabel-variabel penelitian, antara lain minimum, maksimum, mean, dan standar deviasi. Pengukuran rata-rata (mean) merupakan cara yang paling umum digunakan untuk mengukur nilai sentral dari suatu distribusi data. Sedangkan, standar deviasi merupakan perbedaan nilai data yang diteliti dengan nilai rata-ratanya.

Tabel 2. Hasil Statistik Deskriptif

Descriptive Statistics

\begin{tabular}{|l|r|r|r|r|r|}
\hline & N & Minimum & Maximum & \multicolumn{1}{c|}{ Mean } & Std. Deviation \\
\hline X1 & 45 &, 79 & 9,96 & 2,2671 & 1,45184 \\
X2 & 45 & 5,13 & 93,47 & 13,0304 & 12,95610 \\
X3 & 45 & 61,35 & 193,97 & 86,0664 & 19,76904 \\
Y & 45 & 7,53 & 58,29 & 26,7044 & 7,26869 \\
Valid N (listwise) & 45 & & & & \\
\hline
\end{tabular}

Berdasarkan tabel 2 di atas dapat dilihat, maka dapat dijelaskan bahwa Profitabilitas menunjukkan nilai minimum adalah 0,79 dan nilai maksimumnya adalah 
9,96. Mean untuk profitabilitas adalah 2,26, hal ini berarti rata-rata profitabilitas sebesar 2,26. Standar deviasinya 1,45 hal ini berarti terjadi penyimpangan nilai profitabilitas terhadap nilai rata-ratanya yaitu sebesar 1,45 . Investment opportunity set menunjukkan nilai minimum adalah 5,13 dan nilai maksimumnya adalah 93,47. Mean untuk investment opportunity set adalah 13,03, hal ini berarti rata-rata investment opportunity set sebesar 13,03. Standar deviasinya 12,95 hal ini berarti terjadi penyimpangan nilai investment opportunity set terhadap nilai rata-ratanya yaitu sebesar 12,95 .

Likuiditas menunjukkan nilai minimum adalah 61,35 dan nilai maksimumnya adalah 193,97. Mean untuk likuiditas adalah 86,06, hal ini berarti rata-rata likuditas sebesar 86,06. Standar deviasinya 19,76 hal ini berarti terjadi penyimpangan nilai likuiditas terhadap nilai rata-ratanya yaitu sebesar 19,76. Kebijakan Dividen tunai menunjukkan nilai minimum adalah 7,53 dan nilai maksimumnya adalah 58,29. Mean untuk kebijakan dividen adalah 26,70, hal ini berarti rata-rata kebijakan Dividen sebesar 26,70. Standar deviasinya 7,26 hal ini berarti terjadi penyimpangan nilai kebijakan tunai terhadap nilai rata-ratanya yaitu sebesar 7,26.

\section{Tabel 3. Uji Normalitas}

One-Sample Kolmogorov-Smirnov Test

\begin{tabular}{|ll|r|}
\hline & & \multicolumn{1}{|c|}{$\begin{array}{c}\text { Unstandardiz } \\
\text { ed Residual }\end{array}$} \\
\hline $\mathrm{N}$ & & 45 \\
Normal Parameters ${ }^{\mathrm{a}, \mathrm{b}}$ & Mean &, 0000000 \\
& Std. Deviation & 1,08964565 \\
Most Extreme & Absolute &, 164 \\
Differences & Positive &, 164 \\
& Negative &,- 106 \\
Kolmogorov-Smirnov Z & & 1,099 \\
Asymp. Sig. (2-tailed) & &, 178 \\
\hline
\end{tabular}

a. Test dis tribution is Normal.

b. Calculated from data. 
Berdasarkan output SPSS diperoleh nilai Asymp. Sig. (2-tailed) 0,178 yang lebih besar dari 0,05. Hal itu berarti residual data berdistribusi normal.

\section{Tabel 4. Uji Heteroskedastisitas}

\section{Coefficients}

\begin{tabular}{|ll|r|r|r|r|r|}
\hline & & \multicolumn{2}{|c|}{$\begin{array}{c}\text { Unstandardized } \\
\text { Coefficients }\end{array}$} & \multicolumn{2}{c|}{$\begin{array}{c}\text { Standardized } \\
\text { Coefficients }\end{array}$} & \\
\cline { 3 - 4 } Model & \multicolumn{1}{|c|}{ B } & Std. Error & \multicolumn{1}{|c|}{ Beta } & \multicolumn{1}{c|}{ S } & \multicolumn{1}{c|}{ Sig. } \\
\hline 1 & (Constant) & $-3,823$ & 2,820 & & $-1,356$ &, 183 \\
& X1 &,- 024 &, 189 &,- 047 &,- 128 &, 898 \\
& X2 &,- 038 &, 019 &,- 657 & $-2,021$ &, 051 \\
X3 &,- 006 &, 007 &,- 159 &,- 810 &, 423 \\
& X1X3 &,- 271 &, 571 &,- 180 &,- 475 &, 637 \\
& X2X3 & 1,034 &, 581 &, 740 & 1,781 &, 088 \\
\hline
\end{tabular}

a. Dependent Variable: Abres

Berdasarkan hasil pengujian yang ditunjukkan pada Tabel 4 tersebut dapat dilihat bahwa nilai signifikansi dari profitabilitas sebesar 0,898 , investment opportunity set sebesar 0,051, likuiditas sebesar 0,423, interaksi profitabilitas dengan likuiditas sebesar 0,637, interaksi investment opportunity set dengan likuiditas sebesar 0,088, dengan menggunakan alpha 0,05 maka dapat disimpulkan bahwa model regresi tidak mengandung adanya heteroskedastisitas.

\section{Tabel 5. Uji multikolinearitas}

\section{Coefficients}

\begin{tabular}{|ll|r|c|}
\hline \multirow{2}{*}{ Model } & \multicolumn{2}{|c|}{ Collinearity Statistics } \\
\cline { 3 - 4 } & Tolerance & VIF \\
\hline 1 & X1 &, 164 & 6,101 \\
& X2 &, 208 & 4,818 \\
& X3 &, 571 & 1,750 \\
& X1X3 &, 152 & 6,560 \\
& X2X3 &, 185 & 5,397 \\
\hline
\end{tabular}

a. Dependent Variable: Y 
Tabel 5 menunjukkan bahwa nilai tolerance variabel profitabilitas sebesar 0,164 , investment opportunity set sebesar 0,208, likuiditas sebesar 0,571, interaksi profitabilitas dan likuiditas sebesar 0,152, interaksi investment opportunity set dengan likuiditas sebesar 0,185 dan variance inflation factor (VIF) variabel profitabilitas sebesar 6,101, investment opportunity set sebesar 4,818, likuiditas sebesar 1,750, interaksi profitabilitas dan likuiditas sebesar 6,560 dan interaksi investment opportunity set dengan likuiditas sebesar 5,397 sehingga tidak ada variabel bebas yang nilai tolerance kurang dari 0,1 atau variance inflation factor (VIF) kurang dari 10, maka disimpulkan tidak ada multikolinearitas antara variabel bebas dalam model regresi.

\section{Tabel 6. Uji Autokorelasi}

\begin{tabular}{|l|r|r|r|r|r|}
\multicolumn{7}{|c|}{ Model Summary } \\
\hline Model & R & R Square & $\begin{array}{c}\text { Adjusted } \\
\text { R Square }\end{array}$ & $\begin{array}{c}\text { Std. Error of } \\
\text { the Estimate }\end{array}$ & $\begin{array}{c}\text { Durbin- } \\
\text { Watson }\end{array}$ \\
\hline 1 &, $895^{\mathrm{a}}$ &, 802 &, 776 & 1,15739 & 1,840 \\
\hline
\end{tabular}

a. Predictors: (Constant), X2X3, X1X3, X3, X2, X1

b. Dependent Variable: $Y$

Uji autokorelasi dapat dilakukan uji Durbin-Watson terhadap variabel pengganggu (disturbance error term)nya. Dengan tingkat kepercayaan 5\%, untuk $n=45$ dan $k^{\prime}=5$, maka nilai Durbin Watson: $d_{1}=1,2$ dan $d_{u}=1,7$. Karena $D_{1}<D_{W}>D_{U}$ dan $D_{1}<\left(4-D_{W}\right)>D_{U}$ atau $1,2<1,840>1,7$ dan $1,2<(4-1,840)>1,7$ dapat disimpulkan bahwa tidak terdapat autokorelasi antara data pada masa sebelumnya $(t)$ dengan data sesungguhnya $\left(t_{1}\right)$. 
Tabel 7. Uji moderated regresion analysis (MRA)

\begin{tabular}{|c|c|c|c|c|c|c|c|c|}
\hline \multicolumn{9}{|c|}{ Coefficients } \\
\hline \multirow{2}{*}{\multicolumn{2}{|c|}{ Model }} & \multicolumn{2}{|c|}{$\begin{array}{c}\text { Unstandardized } \\
\text { Coefficients }\end{array}$} & \multirow{2}{*}{$\begin{array}{c}\begin{array}{c}\text { Standardized } \\
\text { Coefficients }\end{array} \\
\text { Beta }\end{array}$} & \multirow[b]{2}{*}{$\mathrm{t}$} & \multirow[b]{2}{*}{ Sig. } & \multicolumn{2}{|c|}{ Collinearity Statistics } \\
\hline & & $\mathrm{B}$ & Std. Error & & & & Tolerance & VIF \\
\hline$\overline{1}$ & (Constant) & 14,497 & 4,437 & & 3,267 &, 002 & & \\
\hline & $\mathrm{X} 1$ & ,219 & ,103 & ,130 & 2,128 & ,047 & ,164 & 6,101 \\
\hline & $\mathrm{X} 2$ &,- 171 & ,030 &,- 908 & $-5,798$ &, 000 & ,208 & 4,818 \\
\hline & X3 & ,016 & ,006 & ,129 & 2,802 & ,018 &, 571 & 1,750 \\
\hline & $\mathrm{X} 1 \mathrm{X} 3$ & 1,890 & ,898 & ,384 & 2,105 & ,042 &, 152 & 6,560 \\
\hline & $\mathrm{X} 2 \times 3$ & ,631 & ,256 & ,138 & 2,467 &, 039 & ,185 & 5,397 \\
\hline
\end{tabular}

a. Dependent Variable: $Y$

Berdasarkan Tabel 7 dapat dibuat suatu model persamaan regresi yaitu sebagai berikut.

$$
Y=14,497+0,219 X_{1}-0,171 X_{2}+0,016 X_{3}+1,890 X_{1} X_{3}+0,631 X_{2} X_{3}
$$

Interprestasi dari persamaan diatas adalah Nilai koefisien $\left(\beta_{1}\right)$ sebesar 0,219 . Nilai koefisien yang positif menunjukan bahwa apabila profitabilitas ditingkatkan satu satuan, maka kebijakan dividen tunai akan meningkat sebesar 0,219 dengan asumsi variabel lainnya dianggap konstan. Nilai koefisien $\left(\beta_{2}\right)$ sebesar $-0,171$. Nilai koefisien negatif menunjukan bahwa apabila investment opportunity set ditingkatkan satu satuan, maka kebijakan dividen tunai akan menurun sebesar 0,171 dengan asumsi variabel lainnya dianggap konstan. Nilai koefisien $\left(\beta_{3}\right)$ sebesar 0,016. Nilai koefisien yang positif menunjukan bahwa apabila likuiditas ditingkatkan satu satuan, maka kebijakan diveden tunai akan meningkat sebesar 0,016 dengan asumsi variabel lainnya dianggap konstan. Nilai koefisien $\left(\beta_{4}\right)$ sebesar 1,890. Menunjukan bahwa efek moderasi yang diberikan adalah positif. Hal ini berarti semakin tinggi variabel interaksi profitabilitas dengan likuiditas terhadap kebijakan dividen tunai (Y) akan meningkat dengan asumsi variabel lainnya dianggap konstan. Nilai koefisien $\left(\beta_{5}\right)$ sebesar 0,631. Menunjukan bahwa efek moderasi yang diberikan adalah positif. Hal ini berarti semakin tinggi interaksi investment 108 | widya_akuntansi 
opportunity set dengan likuiditas $\left(\mathrm{X}_{3}\right)$ terhadap kebijakan Dividen tunai $(\mathrm{Y})$ akan meningkat dengan asumsi variabel lainnya dianggap konstan.

Tabel 8. Uji Koefisien Determinasi $\left(\mathrm{R}^{2}\right)$

Model Summary

\begin{tabular}{|l|r|r|r|r|r|}
\hline Model & \multicolumn{1}{|c|}{$\mathrm{R}$} & R Square & $\begin{array}{c}\text { Adjusted } \\
\text { R Square }\end{array}$ & $\begin{array}{r}\text { Std. Error of } \\
\text { the Estimate }\end{array}$ & $\begin{array}{c}\text { Durbin- } \\
\text { Watson }\end{array}$ \\
\hline 1 &, $895^{\mathrm{a}}$ &, 802 &, 776 & 1,15739 & 1,840 \\
\hline
\end{tabular}

a. Predictors: (Constant), X2X3, X1X3, X3, X2, X1

b. Dependent Variable: $Y$

Berdasarkan Tabel 8 nilai adjusted $\mathrm{R}^{2}$ sebesar 0,776, ini berarti sebesar 77,6 persen variabel profitabilitas, investment opportunity set, likuiditas, interaksi profitabilitas dengan likuiditas, interaksi investment opportunity set dengan likuiditas, sedangkan sisanya sebesar 22,4 persen dipengaruhi oleh variabel lain yang tidak dimasukan dalam penelitian seperti EPS dan DER.

\section{Tabel 9. Uji Kelayakan Model (Uji F)}

ANOVA

\begin{tabular}{|c|c|c|c|c|c|c|}
\hline Model & & $\begin{array}{l}\text { Sum of } \\
\text { Squares }\end{array}$ & $\mathrm{df}$ & Mean Square & $\mathrm{F}$ & Sig. \\
\hline \multirow[t]{3}{*}{1} & Regression & 211,132 & 5 & 42,226 & 31,523 &, $000^{\mathrm{a}}$ \\
\hline & Residual & 52,242 & 39 & 1,340 & & \\
\hline & Total & 263,374 & 44 & & & \\
\hline
\end{tabular}

a. Predictors: (Constant), X2X3, X1X3, X3, X2, X1

b. Dependent Variable: $Y$

Berdasarkan Tabel 9 diperoleh nilai dari signifikansi 0,000 yang lebih kecil dari 0,05 menunjukan model penelitian ini layak untuk digunakan sebagai alat analisis untuk menguji pengaruh variabel dependen pada variabel independen. Ini berarti bahwa ada pengaruh antara variabel profitabilitas, investment opportunity set, likuiditas, interaksi profitabiltias dengan likuiditas, interaksi investmen opportunity set dengan likuiditas, secara simultan terhadap variabel kebijakan dividen tunai. 
Tabel 10. t-test

\begin{tabular}{|c|c|c|c|c|c|c|c|c|}
\hline \multicolumn{9}{|c|}{ Coefficients } \\
\hline \multirow{2}{*}{\multicolumn{2}{|c|}{ Model }} & \multicolumn{2}{|c|}{$\begin{array}{c}\text { Unstandardized } \\
\text { Coefficients }\end{array}$} & \multirow{2}{*}{$\begin{array}{c}\begin{array}{c}\text { Standardized } \\
\text { Coefficients }\end{array} \\
\text { Beta }\end{array}$} & \multirow[b]{2}{*}{$\mathrm{t}$} & \multirow[b]{2}{*}{ Sig. } & \multicolumn{2}{|c|}{ Collinearity Statistics } \\
\hline & & $\mathrm{B}$ & Std. Error & & & & Tolerance & VIF \\
\hline \multirow[t]{6}{*}{1} & (Constant) & 14,497 & 4,437 & & 3,267 &, 002 & & \\
\hline & $\mathrm{X} 1$ & ,219 & ,103 & , 130 & 2,128 &, 047 & , 164 & 6,101 \\
\hline & $\mathrm{X} 2$ &,- 171 & ,030 &,- 908 & $-5,798$ &, 000 & ,208 & 4,818 \\
\hline & X3 & ,016 & ,006 & ,129 & 2,802 & ,018 &, 571 & 1,750 \\
\hline & $\mathrm{X} 1 \mathrm{X} 3$ & 1,890 & ,898 & ,384 & 2,105 & ,042 & , 152 & 6,560 \\
\hline & $\mathrm{X} 2 \times 3$ &, 631 & ,256 & , 138 & 2,467 & ,039 & , 185 & 5,397 \\
\hline
\end{tabular}

a. Dependent Variable: $Y$

Hasil perhitungan diperoleh koefisien regresi sebesar 0,219 nilai $\mathrm{t}_{1}$-hitung adalah 2,128 dan nilai sig $0,00<0,05$ maka Ho ditolak atau H1 diterima, berarti memang benar ada pengaruh positif dan signifikan antara profitabilitas secara parsial terhadap kebijakan Dividen tunai. Hasil penelitian memberikan makna semakin tinggi profitabilitas maka semakin tinggi kebijakan dividen tunai, begitu sebaliknya.

Profitabilitas adalah kemampuan perusahaan untuk menghasilkan keuntungan dari modal yang diinvestasikan. Profitabilitas dalam penelitian ini diproksikan dengan return on asset (ROA). ROA merupakan ukuran kemampuan perusahaan menghasilkan laba bersih berdasarkan tingkat asset tertentu (Hanafi, 2004: 42). Semakin tinggi profitabilitas sebuah perusahaan, maka semakin tinggi pula arus kas dalam perusahaan tersebut, dan diharapkan perusahaan akan membayar dividen yang lebih tinggi. Dewi (2016) dengan judul pengaruh investment opportunity set, free cash flow, struktur modal, profitabilitas dan likuiditas terhadap kebijakan dividen pada perusahaan manufaktur yang terdaftar di BEI tahun 2012-2014, menunjukan bahwa profitabilitas berpengaruh terhadap kebijakan dividen dan sangat signifikan. Penelitian Suharli (2007) tentang pengaruh profitability dan investment opportunity set terhadap kebijakan dividen tunai perusahaan dengan likuiditas 
sebagai variabel pemoderasi pada perusahaan manufaktur yang terdaftar di BEI periode 2002-2003 menunjukan profitabilitas berpengaruh terhadap kebijakan dividen tunai perusahaan.

Hasil perhitungan diperoleh koefisien regresi sebesar $-0,171$ nilai $t_{2}$-hitung adalah 5,798 dan nilai sig 0,00 $<0,05$ maka Ho ditolak atau $\mathrm{H} 2$ diterima, berarti memang benar ada pengaruh negatif dan signifikan antara investment opportunity set secara parsial terhadap kebijakan Dividen tunai, hal ini berarti investment opportunity set berpengaruh negatif dan signifikan terhadap kebijakan Dividen tunai. Nilai koefisien regresi bernilai negatif artinya semakin tinggi investment opportunity set maka semakin rendah kebijakan dividen tunai, begitu sebaliknya.

Investment opportunity set adalah kesempatan perusahaan untuk melakukan investasi baru yang menguntungkan karena kondisi perusahaan mengalami pertumbuhan penjualan. Untuk meningkatkan pertumbuhan penjualan, perusahaan memerlukan dana yang besar yang dibiayai sumber internal perusahaan. Penggunaan sumber dana internal untuk keperluan investasi, dan pembayaran dividen tunai. Kesempatan investasi diproksikan price earnings ratio (PER) perusahaan dengan tingkat pertumbuhan yang tinggi berarti memiliki banyak kesempatan investasi. Persamaan antara kesempatan investasi dan kebijakan dividen, yakni keduanya sama-sama bersumber dari laba perusahaan. Laba perusahaan yang akan digunakan untuk membayar dividen kepada pemegang saham dan sisanya ditahan sebagai laba ditahan yang akan digunakan untuk investasi perusahaan yang berguna untuk pertumbuhan di masa yang akan datang. Penelitian Sari (2010) dengan judul analisis pengaruh kepemilikan manajerial, kebijakan hutang, profitabilitas, ukuran perusahaan, dan kesempatan investasi terhadap kebijakan 
dividen tunai menyimpulkan bahwa kepemilikan perusahaan, profitabilitas, ukuran perusahaan, dan set kesempatan investasi secara parsial tidak berpengaruh terhadap kebijakan dividen tunai perusahaan.

Memberikan nilai t hitung sebesar 2,105 dan tingkat signifikansi sebesar 0,042 lebih kecil daripada $\alpha=0,05$. Maka dapat disimpulkan bahwa hipotesis keempat $\left(\mathrm{H}_{4}\right)$ yaitu interaksi profitabilitas dan likuiditas berpengaruh positif terhadap kebijakan Dividen tunai(Y). Maka dapat disimpulkan bahwa likuiditas mampu memoderasi hubungan profitabilitas dengan kebijakan Dividen tunai (Y). Maka dapat disimpulkan bahwa interaksi profitabilitas dan likuiditas berpengaruh positif terhadap kebijakan Dividen tunai. Atau dengan kata lain likuiditas mampu memoderasi pengaruh profitabilitas terhadap kebijakan Dividen tunai.

Likuiditas adalah kemampuan perusahaan dalam memenuhi kewajiban jangka pendeknya dan memenuhi operasional perusahaan. Pihak manajemen akan menggunakan potensi likuiditas untuk mendanai operasi perusahaan atau melunasi kewajiban jangka pendek. Pada perusahaan yang membukukan keuntungan yang lebih tinggi dan ditambah likuiditas yang lebih baik, maka semakin besar jumlah dividen yang akan dibagikan. Suharli (2007) dengan judul pengaruh profitability dan investment opportunity set terhadap kebijakan dividen tunai dengan likuiditas sebagai variabel penguat menyatakan bahwa likuiditas dapat digunakan sebagai variabel pemoderasi karena memberikan hasil yang signifikan pada a -0.10 dalam mempengaruhi profitabilitas dan investment opportunity set terhadap kebijakan dividen tunai. Dengan demikian likuiditas dapat memperkuat pengaruh profitabilitas terhadap kebijakan dividen. 
Variabel interaksi investment opportunity set dengan likuiditas memberikan nilai $\mathrm{t}$ hitung sebesar 2,467 dan tingkat signifikansi sebesar 0,039 lebih kecil daripada $\alpha=0,05$. Maka dapat disimpulkan bahwa hipotesis lima yaitu interaksi investment opportunity set dengan likuiditas berpengaruh positif terhadap kebijakan Dividen tunai. Maka dapat disimpulkan bahwa likuiditas mampu memoderasi hubungan investment opportunity set dengan kebijakan Dividen tunai.

Jika likuiditas perusahaan bagus, perusahaan akan cenderung untuk menggunakan dana kas yang ada untuk membiayai set kesempatan investasi yang tinggi. Oleh karena itu, akan mengurangi dana kas yang tersedia untuk membayar dividen tunai. Penelitian Suharli (2007) dengan judul pengaruh profitability dan investment opportunity set terhadap kebijakan dividen tunai dengan likuiditas sebagai variabel penguat menyatakan bahwa liuiditas dapat digunakan sebagai variabel pemoderasi karena memberikan hasil yang signifikan pada a -0.10 dalam mempengaruhi profitabilitas dan investment opportunity set terhadap kebijakan dividen tunai. Jadi, likuiditas mampu memoderasi investment opportunity set terhadap kebijakan dividen tunai.

\section{SIMPULAN DAN SARAN}

Berdasarkan hasil analisis dan uraian diatas, maka dapat ditarik kesimpulan yaitu profitabilitas dan Investment opportunity set berpengaruh positif dan signifikan terhadap kebijakan Dividen tunai. Sedangkan variabel likuiditas mampu memoderasi hubungan antara varibel profitabilitas dan Investment opportunity set terhadap kebijakan Dividen tunai.

Berdasarkan hasil penelitian ini maka saran bagi Para investor disarankan dalam pengambilan investasi memperhatikan tingkat profitabilitas perusahaan dan set kesempatan 
investasi, karena kedua variabel ini berpengaruh secara signifikan terhadap kebijakan dividen tunai.

\section{DAFTAR PUSTAKA}

Arum, Galuh. (2009). "Pengaruh Profitabilitas Terhadap Kebijakan Dividen dengan Likuiditas Sebagai Variabel Moderator" Skripsi. Yogyakarta: Fakultas Ekonomi Universitas Islam Indonesia.

Ang, Robert, 1997, Buku Pintar: Pasar Modal Indonesia (The Intlligent Guide to Indonesian Capital Market), Mediasoft Indonesia, First Edition : Jakarta.

Brigham, F. Eugene, dan Joel F. Houston. (2011). Manajemen Keuangan buku 2 Edisi 11. Jakarta: Erlangga.

Brigham, F. Eugene, dan Joel F. Houston. (2006). Pasar Modal di Indonesia: Pendekatan Tanya Jawab. Jakarta: Salemba Empat.

Dewi, Aqlima Cendera (2016). "Pengaruh Investment Opportunity Set, Free Cash Flow, Struktur Modal, Profitabilitas dan Likuiditas Terhadap Kebijakan Dividen”. Skripsi. Surakarta : Fakultas Ekonomi dan Bisnis Universitas Muhammadiyah Surakarta 2016.

Darmadji, Tjiptono dan Hendy M Fakhrudin. (2006). Dasar-dasar ManajemenKeuangan. Jakarta: Salemba Empat.

Gaver, JJ dan Keneth M Gaver. 1993. Additional Evidence on The Association Betwen The Investment Opportunuty Set and Corporate Financing, Dividend and Compensation Policies. Journal of Accounting and Economic Vol.1, pp. 233-265.

Ghozali, Imam. (2006). Multivariate Lanjutan dengan Program SPSS. Semarang: Badan Penerbit Universitas Diponegoro.

Hanafi, Mamduh. (2004). Manajemen Keuangan. Yogyakarta: BPFE.

Hartono, J. M. (2010). Teori Portofolio dan Analisis Investasi, Edisi Ketujuh.Yogyakarta: BPFE UGM.

Inneke, Theoral Maria dan Supatmi. (2008). Analisis Investment Opportunity Set dan Profitabilitas dalam Memoderasi Pengaruh Kebijakan Dividen terhadap Tingkat Leverage Perusahaan. Salatiga: Fakultas Ekonomi Universitas Kristen Satya Wacana. 
Jogiyanto. (2010). Metodologi Penelitian Bisnis: Salah Kaprah dan Pengalamanpengalaman. Yogykarta: BPFE.

Jensen, M.C., dan W.H. Meckling. 1976. "The Theory of The Firm: Managerial Behaviour, Agency Cost, and Ownership Structure". Journal of Financial Economics.

Kallapurr.S., dan Trombley, M. K (2001) The Investment Opportunity Set: Deterrninants, Consequences, and Measuremenl, Managerial Finance 27. pp.3-15.

Kadir, Abdul. 2010. Analisis Faktor-Faktor yang Mempengaruhi Kebijakan Dividen Pada perusahaan Credit Agencies Go Public di Bursa Efek Indonesia. Jurnal Manajemen dan Akuntansi, Vol. 11, No. 1, hal: 10-20.

Mariah, Meythi dan Martusa. (2012). "Pengaruh Profitabilitas dan Kesempatan Investasi terhadap Kebijakan Dividen Tunai dengan Likuiditas sebagai Variabel Moderating pada Emiten Pembentuk Indeks LQ 45 Periode 2008-

2010” SNAB 27 Maret 2012. Jakarta: Universitas Kristen Maranatha.

Marpaung, Indrawati Elyzabet dan Bram Hadianto. (2009). "Pengaruh Profitabilitas dan Kesempatan Investasi terhadap Kebijakan Dividen: Studi Empirik pada Emiten Pembentuk Indeks LQ 45 di Bursa Efek Indonesia” Jurnal Akuntansi Vol. 1 No.1 Mei 2009: 70-84. Bandung: Universitas Kristen Maranatha.

Poniasih, Popon. (2006). “Analisis Faktor-Faktor yang Mempengaruhi Dividend Payout Ratio pada Perusahaan Non Keuangan" Skripsi. Yogyakarta: Fakultas Ekonomi Universitas Islam Indonesia.

Pagalung, Gagaring. 2003. Pengaruh Kombinasi Keunggulan dan KeterbatasanPerusahaan terhadap Set Kesempatan (IOS). Jurnal Riset AkuntansiIndonesia. Volume 6, No. 3.

Riyanto, Bambang. (2001). Dasar-dasar Pembelanjaan Perusahaan. Yogyakarta: BPFE.

Suharli, Michell. (2007). "Pengaruh Profitability dan Investment Opportunity Set terhadap Kebijakan Dividen Tunai dengan Likuiditas Sebagai Variabel Penguat". Jurnal Akuntansi dan Keuangan, Vol.9, No.1, Mei 2007: 9-17.

Safrida dan Risanty. (2004). "Hubungan Nilai Set Kesempatan Investasi sebagai Indikator Pertumbuhan Perusahaan terhadap Realisasi Pertumbuhan Perusahaan di Bursa Efek Jakarta," Jurnal Ekonomi Akuntansi. Medan.

Sari, Fitria Ratih. (2010). “Analisis Pengaruh Kepemilikan Manajerial, Kebijakan Utang, Profitabilitas, Ukuran Perusahaan, dan Kesempatan Investasi terhadap 
Kebijakan Dividen" Skripsi. Surakarta: Fakultas Ekonomi Universitas Sebelas Maret.

Sekaran, Uma. (2007). Metodologi Penelitian untuk Bisnis. Buku 1 Jakarta: Salemba Empat. (2007). Metodologi Penelitian untuk Bisnis. Buku 2 Jakarta: Salemba Empat.

Subekti, Imam dan Indra Wijaya Kusuma. (2001). "Asosiasi antara set Kesempatan Investasi dengan Kebijakan Pendanaan dan Dividen Perusahaan, serta Implikasinya pada Perubahan Harga Saham” Jurnal riset akuntansi Indonesia Vol. 4, No. 1, Januari 2001. Surabaya: Universitas Brawijaya.

Sugiyono. (2009). Metode Penelitian Bisnis. Bandung: CV. ALFABETA.

Syarifah, Isyana. (2006). “Analisis Faktor yang Mempengaruhi Dividen Per Lembar Saham pada Perusahaan yang Tergabung dalam LQ-45" Skripsi. Yogyakarta: Fakultas Ekonomi Universitas Islam Indonesia.

Wirjolukito, A. Yanto, H dan Sandy. (2003). "Faktor-faktor yang merupakan Pertimbangan dalam Keputusan Pembagian Dividen pada Perusahaan Go Public di Indonesia" Jurnal Ekonomi dan Bisnis. Jakarta: Universitas Katolik Indonesia Atma Jaya.

Yusuf, Muhammad. (2005). “Analisis Hubungan antara Berbagai Gabungan Proksi Investment Opportunity Set dan Real Growth dengan Menggunakan Pendekatan Confirmatory Factor Analysis." Jurnal Akuntansi dan Investasi vol. 6 No. 2 Juli 2005

.2016. "Buku Pedoman Penulisan Usulan Proposal dan Skripsi”. Denpasar: Universitas Hindu Indonesia. 